\title{
Co-curricular Activities and Its Contribution for Psychosocial Skills Development of Students in Upper Primary Schools of Sinana Woreda, Bale Zone, Oromia
}

\author{
Bezabih Wondimu (PhD) \\ Department of Educational Planning and Management, College of Education and Behavioral Studies, Madda \\ walabu University, Bale-Robe/ Ethiopia \\ Zeleke Gonfa (Mr.) \\ Department of Geography and Environmental Studies, College of Social Science \& Humanities, Madda Walabu \\ University, Bale -Robe/ Ethiopia
}

\begin{abstract}
The purpose of this research article was to explore co-curricular activities and its contributions for psychosocial skill development of students in upper primary schools of sinana Woreda, Bale zone, Oromia. Pragmatic research paradigm that require mixed research approach more specifically a quantitative dominate concurrent triangulation research design was used to assess co-curricular activities and its contributions for psychosocial skill development of students in upper primary schools of sinana Woreda, Bale zone, Oromia.. The study population consisted of 36 upper primary schools, 2484 co-curricular member students, and 180 co-curricular activity coordinating teachers. Systematic and simple random sampling design were used to select samples of 332 students and ten schools. From the selected ten schools, ten vice directors and 50 selected co-curricular activity coordinating teachers were purposively and simple random sampling techniques were used to approach individual samples The instruments used in data collection were questionnaires and interview questions. Data were collected and analyzed using descriptive statistics such as frequencies tables, mean, and standard deviation and inferential statistics, F-test of one-way ANOVA. Qualitative data collected by means of interview were analyzed by means of narration, direct quotations and paraphrasing of the response of the respondents. The analysis made showed that there were active students' engagement and practicing different types of activities in co-curricular activity program in upper primary schools of Sinana Woreda. In addition, the findings of the study revealed that were accounts for more than $78.9 \%$ revealed that co-curricular activities held in upper primary schools of Sinana Woreda were contributed much to the psychosocial skills development of the students. However, there were unresolved challenges that hindered students' effective and efficient devotion to their fullest capacity to do well in co-curricular activities. Therefore, to overcome such challenges and further enhance student's role in co-curricular activities, it was suggested that students, co-curricular activity coordinating teachers, school administration, and school community together with woreda education office have to give special attention to actively engage students, follow up, monitor, and provide all necessary financial and material supply for co-curricular activities.
\end{abstract}

Keywords: Co-curricular, Psychosocial, Practice, Challenges, and Skill development

DOI: $10.7176 / \mathrm{JEP} / 10-28-06$

Publication date:October $31^{\text {st }} 2019$

\section{Introduction}

Background of the Study

The concept of co-curricular activities is varied among different educators. Gill (2015), Joseph (2003) and Chingtham (2016) agreed that co-curricular activity is a program that is out-of-class activity, supervised and/or financed by the school, which provides curriculum-related learning and character-building experiences. Similarly, Singh (2017) explain co-curricular activities as activities conducted on or off school premises by clubs, associations, and organizations of students. Ayele Ishete (2007) also elaborated that co-curricular activities are free and informal activity that help students to gain opportunity to adjust their future life. These activtieis include different school-based clubs such as sport, art, citizenship, gender issues, HIV/AIDS prevention and protection, press, and vocational clubs. These co-curricular activities that have common elements including: regular meetings, an emphasis on skill development, goal orientation, have plan for actions, as well as the direction, supervision, and the leadership of one or more head teachers (Nilson, 2009).

In ancient times co-curricular activities are perceived as residential institution providing opportunities of social contacts on a large scale. The history of co-curricular activities dated back to $19^{\text {th }}$ century when it first appeared in American colleges in the nineteenth century. In Ethiopia too, co-curricular has its root with the introduction of modern education. The 1994 Education policy of the country has given emphasis for co-curricular activity to be implemented in schools (MoE, 1994). Nowadays, schools have co-curricular activity implementing guidelines (Gill, 2015; Chingtham, 2016). 
Paul, and Baskey (2012) stated that co-curricular activities provides additional activities for school students that enhance social interaction, leadership, healthy recreation, self-discipline and self-confidence. These educative activities and experiences of school, comprise experiences inside as well as outside the class room, curricular as well as extra-curricular or co-curricular to cover all facts of growth pattern and ensure balanced development of the child and good citizenship for the country.

Findings of Joseph (2003), Gill (2015), and Bayat (2015) showed that the physical, emotional, social, intellectual and spiritual development of the child is the prime concerns of the school through co-curricular activity engagement. However, in practical schools were giving less emphasis for co-curricular activities worldwide. For instance, in Philippines member of co-curricular activities were not fully satisfied with resources and logistic supplies provided to utilize for the implementation of co-curricular activities (Abrea, 2015).

In Africa, same problems were manifested in school co-curricular activities. finding of Mbugua, Kaagema, and Nelson (2017), and Kisango (2016) research conducted in Kenya showed that in Africa too school based cocurricular activities were not supported well, not monitored and evaluated against the achievement of its goals and objectives.

When we come to Ethiopia, the findings of Ayele Ishete (2007), and Panigrahi and Yadessa (2012) also show that in the schools of Ethiopia too, less emphasis were given in organizing and properly implementing co-curricular activities to improve the personality and the talents of the students through co-curricular activities. In the study area, Sinana woreda, co-curricular activities are not well managed, organized, and effectively implement in all schools in same manner. Furthermore, there is no formal structure who is responsibly plan, co-ordinate, and follow up activities of co-curricular activities from ministry of education to woreda level. Information from woreda education office show that co-curricular activities organized and monitored under school improvement program at woreda level. This encouraged writers to gives special attention to conduct this study. Therefore, the writers of this article believed that unless emphasis is given for both the curricular and co-curricular activities, the very purpose of education would be left unrealized.

\section{Statements of the problem}

Many researches have focused on the influence of co-curricular activities on academic performance and social cohesion among students. To mention some, Jha et.al. (2004) showed that students who participate in co-curricular activities in primary and secondary schools have significantly higher in grade point average and significantly lower absenteeism. Findings of Bayat (2015), showed that the more student engagement in co-curricular activity the less absenteeism from school, the more sociable they are, and the more motivated to attend class. The finding of Farrugia (2015) showed that the more students engaged in co-curricular activities the more they manage their emotion, and bring over all behavioral changes. The findings of Saleem (2010) also showed that co-curricular activities have positive effect on physical and mental development of students. A research conducted by Ayele Ishete (2007) on the practice of co-curricular activities in Addis Ababa University revealed that the actual practices of extra-curricular activities was inadequate and entangled by shortage of time, finance and materials.

As it can be indicated in these research findings, many researches have been done to investigate co-curricular activities' contribution to academic performance of the students but, less emphasis is given for the non-academics like contribution of co -curricular activities for psychosocial more specifically( psychological and social) skills development of students

Therefore, the intention of the writers was to investigate the ongoing co-curricular activities and its contributions for psychosocial skill development of students in upper primary schools of sinana Woreda, Bale zone, Oromia. In assessing the psychosocial skill development, the investigators takes into consideration relationship building skill and conflict management skill from social skill and self-awareness and respect skill from psychological skills. These variables are not well addressed by researches conducted so far. To this end, to realize the purpose of the study, the following basic research questions were raised and need to answer in the course of the study.

1. To what level are co-curricular activities practiced in upper primary schools of Sinana Woreda, Bale Zone?

2. To what extent do co-curricular activities contribute to psychosocial development of the students?

3. What are the challenges that affect effective implementation of co-curricular activities in Sinana Woreda of Bale Zone?

\section{Scope of the study}

The study was geographically delimited to upper primary schools found in Sinana Woreda, Oromia Regional State. The research work takes in to focus the practices and challenges of co-curricular activities. Hence, the research delimited its variables to the practices and challenges going on at school level, the supports provided for cocurricular activities, and psycho-social skill developments acquired by students at large in relation to five purposefully selected co-curricular activities like relationship building skill and conflict management skill from 
social skill and self-awareness and respect skill from psychological skills undergone in sample schools.

\section{Theoretical and conceptual framework \\ Theoretical framework}

The developmental perspective that underpins co-curricular activities research considers co-curricular activities as contexts that support student development which result from the interactions of individuals and their social context Mbugua, Kagema, and Nelson, (2017). They found that co- curricular activities participation allowed high school youths to integrate with their social environment, as well as obtain negotiation and cooperation skills. As a result, the theoretical framework of this research is based on the philosophical principles of social constructivism that says human beings' understanding and knowledge are created in interactions among individuals (Guba \& Lincoln, 1994). The nature of social constructivism engages learners and teachers as co-constructors of their knowledge and meaningful.

Bayat (2015) explained that learning occurs when individuals are actively engaged in activities creating relationships that will directly affect what they learn. in this process teachers act as supporters of students; students work in collaboration with teachers to construct shared meanings.

In this scenario that the research article attempt to explore how students become involved in co-curricular activities held in schools. In this research article, writers of this article tried to look at how students are engaged in co-curricular activities to develop relationships skills, conflict management skill, self-awareness and respect and tolerance skill development. A social constructivist perspective helps me to go beyond the individual student and focus on the interactions among the clubs' members and to see how students are engaged.

\section{Conceptual framework}

The purpose of the research article as to co-curricular activities and its contributions for psychosocial skill development of students in upper primary schools of sinana Woreda, Bale zone, Oromia. This involves identifying the ongoing practices of co-curricular activities in helping the acquisition of social and psychological skills among students. As well, finding out challenges that obscure the better practices of co-curricular activities that in turn hinder psychosocial skill development of students and to pin point major contribution of co-curricular activities to the psychosocial development of the students.

Hence, the following diagram presents the conceptual framework of this research article that consists of a set of concepts that underlie the research process and data collection. On one hand, the main concept is psycho social skill development of students through co-curricular activity as dependent variables (conflict management skill, relationship skill, self-awareness and respect and tolerance). On the other hand, supports (school-based infrastructure, financial and material resources, head teacher roles) and barriers (lack of time, shortage of resource, weak support from head teachers) as independent variables in practicing co-curricular activity.

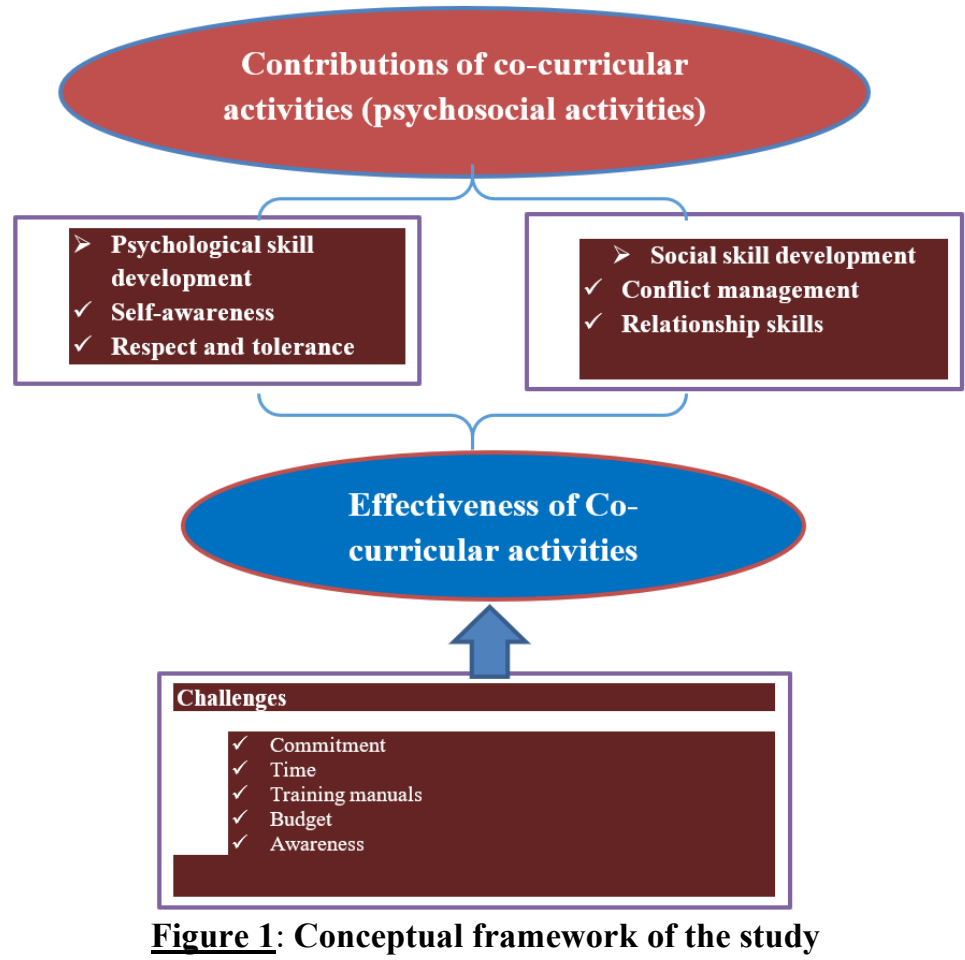




\section{Research methods and design of the study}

\section{Paradigm, methodology and design of the study}

As already mentioned in the outset of the study, the main concern of writes was to investigate the ongoing cocurricular activities and its contributions for psychosocial skills development of the students through engagement in co-curricular activities. To achieve the purpose of the study, the pragmatic paradigm was used as guiding lens to investigate the practices and challenges of co-curricular activities in Sinana woreda, Bale Zone, Oromia. Creswell (2009) explains pragmatic paradigm as it is important for focusing on the research problems and using pluralistic approaches to collect and analyze data. Because as it is stated by Creswell (2009) pragmatic paradigm has been mostly proposed and argued as providing philosophical and methodological foundations to the use of mixed research method.

In connection to this, mixed reach method more specifically a quantitative dominated concurrent triangulation mixed research design was applied. Because the main concern of the writers was to triangulate data collected from different sources to confirm the finding through converging responses. In doing so, writes wanted to overcome the weakness of single data source so that qualitative data and quantitative data are complement each other to cross validate. Thus, the use of the different and independent measuring instruments permitted the writers to provide a precise picture of the diversity of the phenomena in relation with its characteristics. The quantitative data were collected from students and teachers using questionnaires was also used to gather data. Concurrently, the researcher was conducted interviews with school vice directors and woreda experts to collect qualitative data.

\section{Population of the study}

This research article designed to carry out in government owned upper primary schools of Sinana woreda Bale Zone, Oromia. There are 36 upper primary schools in the woreda. Out of which $10(28 \%)$ schools was selected using lottery method. Singh and Masuku (2014) stated that in a research for which the total population size is known, to get optimum representative sample size researcher might use $20 \%-30 \%$ of population.

In connection to this, all students of grade 5-8 who were registered to participate in co-curricular activities in 2018 academic year was sample frame of this study. In addition, teachers who were assigned to coordinate cocurricular activities and vice directors of upper primary schools of Sinana woreda were also population for this study.

\section{Sampling and sample design}

Best, and Kahn (2006) explained that sampling design is the process of selecting sample from given population. To this effect both probability and non-probability sample design was used to select the representative samples. Simple random sampling techniques specifically lottery method was used to select 10 (28\%) sample schools from 36 sample frames of upper primary schools of Sinana Woreda, Bale Zone. Total population of students were stratified to each sample schools to maintain proportion of the population distribution. Systematic random sampling technique was used to determine amount of sample elements to be drawn from each school, and within school from each co-curricular activity to keep the proportion of population distribution in each stratum. Using sample size determining formal of Yamane (1967) given blow, 332 sample students were selected using systematic random sampling techniques. Later, from the lower stratum, sample unit was drawn using lottery method. From each sample schools, teachers who were assigned to co-ordinate co-curricular activities are purposively selected to fill the questionnaires. Sample schools vice directors and upper primary school's supervisor at woreda level were also purposively selected for interviews and focus group.

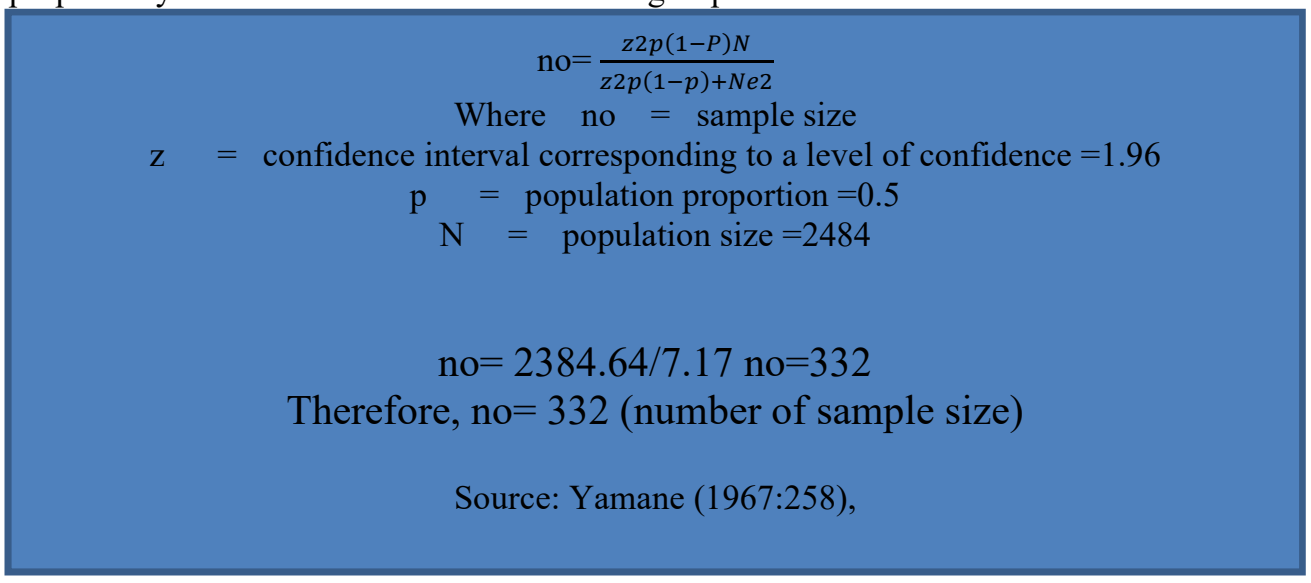

Types and sources of data

For this research article, both primary and secondary data were used. Primary data were collected from students, 
teachers, vice directors and woreda education office expert assigned to coordinate co-curricular activities using appropriate tools. Secondary data were obtained published and unpublished literatures.

\section{Data collection tools}

As it was explained earlier, the paradigm used for this research article was pragmatism and the method preferred that go in line with the preferred perspective is mixed research approach. Hence, questionnaires, and interviews questions were tools used. In order to gather the data two types of questionnaires were prepared. One was for students and the other was for teachers who coordinate co-curricular activities. There were also two types of interviews conducted. One was with vice director of the school and the other was with woreda level experts responsible for coordinating co-curricular activities. The investigator was also used observation check list to see practical situation about co-curricular activities, its infrastructure, and students' engagement in co-curricular activities.

\section{Validity and reliability of instruments}

Firstly, questionnaires were prepared in English and later translated into Afan Oromo to make it easily understandable by sample elements. Back translation was also done to maintain the equivalence of the former versions. All tools were checked by language experts to check its clarity, comprehensiveness and overall quality of language construction. The tools were checked by Sociology and psychology experts for its cultural viability, and free of partisanship. Curriculum experts were also checked it out for the adequacy and relevance of tools in terms of scientific and professional approaches. Furthermore, the instruments were pilot tested in schools which are not selected as sample. Based on the pilot result appropriate correction was made. Reliability test was conducted using split half Cronbach alpha. As it was seen from the given Table 1, the test result of Cronbach alpha was 0.890 that show the instrument was reliable to collect appropriate data. After all, the quality of instrument is checked and necessary correction was made, and dispatched the tools to collect data.

Table 1: Reliability for pilot test using Cronbach Alpha

\begin{tabular}{llll}
\hline R. N & Variables to be measures & No of items & Cronbach's Alpha \\
\hline 1 & Social skills & 5 & \\
& A. Relationship Skills & 5 & 0.950 \\
& A. Conflict management skills & & 0.933 \\
2 & Psychological skills & 5 & \\
& A. Self-awareness skill & 5 & 0.983 \\
& B. Respect and Tolerance & $\mathbf{2 5}$ & 0.776 \\
\hline Total & & & $\mathbf{0 . 8 9 0}$ \\
\hline
\end{tabular}

\section{Method of data analysis}

Since collected data have both qualitative and quantitative form, the qualitative and quantitative data analyzing techniques were used. Close ended questionnaires were analyzed using quantitative techniques such as frequency distribution tables, percentages mean, standard deviations, and one-way ANOVA. Frequency table and percentage are used to see proportion of respondents while measuring, level of participation, and psycho-social skills acquired. Measures of central tendency like mean and standard deviation were used to see variability among responses of respondent students and teachers. One-way ANOVA was also included where necessary to check out the existence of variability between mean values of responses of group of students from different co-curricular activities. Interviews questions were also discussed under each topic following quantitative results. This could be done through direct quoting, paraphrasing and narrating the sayings of respondent to support, oppose and / or complement quantitative data. To do so, SPSS version 20 software were used.

\section{Data presentation, analysis and interpretation of data}

This part of deals with the presentation, analysis and interpretation of data obtained from co-curricular activity member students, co-curricular activity coordinating teachers, schools vice directors and Woreda education office experts who assigned to follow co-curricular activity that are taken as sample. To do so, the data were gathered though questionnaires from students and teachers; and from school vice directors and woreda experts through interviews. Out of the 332-total number of questionnaires distributed to students $326(98.5 \%)$, and to teachers 50 $(100 \%)$ where returned and used. Apart from this, total number of 10 school vice directors and one woreda experts were take part in interviews.

For easy analysis and interpretation of the of the response of the respondents, the writers used five leveled Liker scale of measurement that set in ordinal scale ranging from one to five in order of degree of agreements or disagreements of respondents with questions presented. The writers assumed three as expected mean of responses. This expected mean could be calculated as: 


$$
\text { Expected } \operatorname{mean}(x)=\frac{1+2+3+4+5}{5}=3
$$

It was expected that when cumulative mean of respondent is greater than the expected mean which is three, majority of respondents positively accept the concepts of the item, and when cumulative mean of respondent was below expect mean which is three, respondent negatively accept the items. In addition, the researcher also assumed that there is no significant variability between the distribution of the responses of students from different cocurricular activities either in agreeing or disagreeing or positively or negatively reacting to the questions set under each heading. This could be tested using one-way ANOVA for total respondent students of 326 engaged in cocurricular (of which 71 in sports, 54 of them in Mini-media, 65 in Civic and Ethics, 83 in Gender issues, 53 of the in HIV/AIDS protection co-curricular activities) with between group df 4 and within group df of 324 and total df of 325 using Alpha 0.05 with $95 \%$ confidence level.

\section{Contributions of co-curricular activities for psychosocial skill development}

\subsection{Social Skill Developments in Co-curricular Activity}

Mbugua, Kaagema, and Nelson (2017) stated that co-curricular activities play a very crucial role in social development and cognitive development of individuals particularly at the early stage of development. Mbugua, Kaagema, and Nelson further stated that participation in co-curricular activity to gain over all healthy psycho social development. The finding of Abrea (2015) also showed that educational program must embody activity beyond class room that involves students and foster values that come from social interaction and unified efforts. Among many social skills relationship skill and conflict management skills are discussed as follows:

\section{i. Relationship Skill development}

Mancha, S.A. and Ahmed, A. (2016) stated that co-curricular activities can strengthen the interaction between the students and at the same time promoting integration between the different groups that uphold and strengthen their collaboration. The following table used to see relationship skill development.

\section{Table 2: Students Relationship Skills Development}

\begin{tabular}{|c|c|c|c|c|c|c|c|c|c|c|c|c|c|c|c|c|c|}
\hline \multirow{6}{*}{$\begin{array}{l}\mathbf{N} \\
1\end{array}$} & \multirow{6}{*}{$\begin{array}{l}\text { Variables / items/ } \\
\begin{array}{l}\text { In co-curricular activity session, it is hard to interact } \\
\text { with each other among students from different grade, } \\
\text { sex, religion, ethnic }\end{array}\end{array}$} & \multirow{4}{*}{$\begin{array}{l}\begin{array}{l}\text { Respond } \\
\text { ents }\end{array} \\
\text { Students }\end{array}$} & \multicolumn{15}{|c|}{ Responses in five level Likert Scales } \\
\hline & & & \multicolumn{2}{|c|}{ St.disagree } & \multicolumn{2}{|c|}{ Disagree } & \multicolumn{2}{|c|}{ Undecide } & \multicolumn{2}{|c|}{ Agree } & \multicolumn{2}{|c|}{ St. Agree } & \multicolumn{2}{|c|}{ Statistics } & \multicolumn{3}{|c|}{$\begin{array}{l}\text { ANOVA between group of } \\
\text { students }\end{array}$} \\
\hline & & & $\mathrm{F}$ & $\%$ & $\mathrm{~F}$ & $\%$ & $\mathrm{~F}$ & $\%$ & $\mathrm{~F}$ & $\%$ & $\mathrm{~F}$ & $\%$ & $\mathrm{x}$ & SD & F obt. & F. crt. & Sig. \\
\hline & & & 111 & 34 & 140 & 42.9 & 28 & 8.6 & 38 & 11.7 & 9 & 2.8 & 2.06 & 1.06 & 1.682 & 2.45 & .154 \\
\hline & & Teachers & 11 & 22 & 20 & 40 & 5 & 10 & 12 & 24 & 2 & 4 & 2.48 & 1.19 & & & \\
\hline & & Total & 122 & 32.4 & 160 & 42.6 & 33 & 8.8 & 50 & 13.3 & 11 & 2.9 & 2.22 & 1.09 & & & \\
\hline \multirow[t]{3}{*}{2} & \multirow{3}{*}{$\begin{array}{l}\text { Member students are shy and fear to interact with co- } \\
\text { curricular activity coordinating teacher to express their } \\
\text { feeling and discuss on matter, thus they prefer to keep } \\
\text { quite. }\end{array}$} & Students & 150 & 46 & 133 & 40.8 & 15 & 4.6 & 23 & 7.1 & 5 & 1.5 & 1.77 & 0.93 & .738 & 2.45 & .567 \\
\hline & & Teachers & 18 & 36 & 21 & 42 & 1 & 2 & 10 & 20 & 0 & 0 & 2.06 & 1.09 & & & \\
\hline & & Total & 168 & 44.7 & 154 & 41 & 16 & 4.3 & 33 & 8.8 & 5 & 1.3 & 1.81 & 0.96 & & & \\
\hline \multirow[t]{3}{*}{3} & Member students work in group and build team sprit & Students & 5 & 1.5 & 4 & 1.2 & 9 & 2.8 & 45 & 13.8 & 263 & 80.7 & 4.71 & 0.72 & 1.205 & 2.45 & .309 \\
\hline & & Teachers & 0 & 0 & 0 & 0 & 2 & 4 & 23 & 46 & 25 & 50 & 4.46 & 0.47 & & & \\
\hline & & Total & 5 & 1.3 & 4 & 1.1 & 11 & 2.9 & 68 & 18.1 & 288 & 76.6 & 4.68 & 0.71 & & & \\
\hline \multirow[t]{3}{*}{4} & There is sense of inclusion and harmony relationship & Students & 12 & 3.7 & 14 & 4.3 & 16 & 4.9 & 85 & 26.1 & 199 & 61 & 4.37 & 1.01 & 1.949 & 2.45 & .102 \\
\hline & & Teachers & 0 & 0 & 3 & 6 & 2 & 4 & 27 & 54 & 18 & 36 & 4.2 & 0.78 & & & \\
\hline & & Total & 12 & 3.2 & 17 & 4.5 & 18 & 4.6 & 112 & 29.8 & 217 & 57.7 & 4.34 & 0.98 & & & \\
\hline \multirow[t]{3}{*}{5} & All members' co-curricular activities are easily & Students & 3 & 0.9 & 17 & 5.2 & 7 & 2.1 & 69 & 21.2 & 230 & 70.6 & 4.5 & 0.85 & .176 & 2.45 & .951 \\
\hline & whenever they want. & Teachers & 0 & 0 & 4 & 8 & 3 & 6 & 17 & 34 & 26 & 52 & 4.3 & 0.91 & & & \\
\hline & & Total & 3 & 0.9 & 21 & 5.6 & 10 & 2.7 & 86 & 22.9 & 256 & 68.1 & 4.43 & 0.85 & & & \\
\hline
\end{tabular}

The above table 2 showed about the responses given by students and teachers on relationship skill developments. The first question reflects that in co-curricular activity session it is hard to interact with each other among students from different grades, sex, religion and ethnic. Regarding this statement out of 326 respondent students $251(76.9 \%)$ of respondent students, out of 50 respondent teacher $31(62 \%)$ of them and out of 376 total respondents $282(75 \%)$ of them are disagreed with the idea stated.

The mean values of respondent students, teachers, and total mean are 2.06, 2.48 and 2.22 respectively. These mean values are lies in between strongly disagree and disagree, bellow expected mean that is three. This revealed that majority of respondents were negatively respond to the question that stated "In co-curricular activity session, it is hard to interact with each other among students from different grade, sex, religion, and ethnic". The mean value of students 2.06 and mean value of teachers 2.48 which is less than expected mean value three that show majority of both students and teachers negatively react to the statements, there is variability between them. As it was seen from table 2, F-obtained for this question is 1.682 which is less than F-critical of 2.45 that show there is no significance difference between different group of students. That means there is no variability between group 
of students from five selected co-curricular activities in agreeing or disagreeing with the idea that there is hard to interact with each other among students.

From all these analyses made it was concluded that out of 376 total respondents $282(75 \%)$ of them disagreed that it is hard to interact with each other among students from different grades, sex, religion and ethnic. By implication this show that students easily interact with each other even though they are from different background. This finding was supported by findings of Bayat (2015) stating that diversity among students with respect to ages, genders, grade and ethnicities were noticeable in school justice club. People become more accepting of each other when they know them and interact more.

Regarding the second question that was used to measure relationship skill that refers as "member students are shy and fear to interact with co-curricular activity coordinating teacher to express their feeling and discuss on matter, as a result they prefer to keep quiet". Out of 326 respondent students $283(86.8 \%)$ of them and out of 50 respondent teachers $39(78 \%)$ of them disagreed with the shyness and fearing of students to interact with their teachers. In total, out of 376 respondents $322(88.7 \%)$ of respondents are disagreed with the statement, to support the fact that students are easily interact with their teacher without fear and shyness.

In referring to question three which stated about working in group and team sprit building among students. Out of the total 326 respondent students about $308(94.5 \%)$ of respondents and out of 50 respondent teachers 48 $(96 \%)$ of them agreed that there is strong group work and team sprit building culture in co-curricular activity program. From 376 total respondents 358 (95.4\%) agreed that there were strong team sprit building culture of collaboration among co-curricular activities member students.

The mean value of students' response is 4.71 , teachers' response is 4.46 and in aggregates responses of teachers and students which is 4.68 fall in-between agree and strongly agree region which highly greater than expected mean value of three. These facts witnessed that there were strong team work and team building culture among students who involved in co-curricular activities. One-way ANOVA analysis made clearly depicted that Fobtained which is 0.738 which is less than F-critical 2.45. this data show that there is no variability between group of students of the five selected co-curricular activities in agreeing with the fact that member students work in group and build team spirit.

Therefore, it was concluded that co-curricular activities are effective mean of building strong team work, collaboration and relationship skills. Dhanmahar (2014), Bayat (2015), and Mancha, S. A. and Ahmed, A. (2016) findings clearly support this finding by stating that co-curricular activity helped students to develop teamwork and better communication, able to develop strong bonds with each other.

Regarding question four which stated about the existence of sense of inclusion and harmony relationship among members of co-curricular activity, out 376 students, majority of respondent that account for 284 (87.1\%) that there were strong relationship and sense of inclusion among students. Similarly, out of 50 respondent teachers $45(90 \%)$ of them agreed that there is inclusive approaches and harmonic relationship among member of cocurricular activities.

In supporting data obtained through questionnaires, an informative data obtained from schools' vice director and woreda expert explained that: there is strong linkage and better relationship among students in co-curricular activities. Therefore, it was concluded that co-curricular activities are best means of developing sense of cooperation, collaboration, harmonic relationship, and inclusion.

In supporting this findings Bayat (2015), Abrea (2015) clearly depicted that cooperation was noticeable among students from different backgrounds. In group work there is respectful, warm, inclusive and collaborative relationship were seen among all students. Furthermore, my finding was supported by findings of Mancha, S.A. and Ahmed, A. (2016) who stated that co-curricular activities are capable to promote the spirit to serve, cooperation and helping each other which are vital aspects in establishing a harmonious society.

Regarding the last question used to assess level of relationship that focus on student's relationship with teachers. Out of 376 respondent students 299 (91.8\%) of them strongly that students could easily communicate with their teachers. As it was seen from table 10 above the mean value of students is 4.5 , that of teachers is 4.3 and aggregates of both responses is 4.43. this indicated that all mean found in-between agree and strongly agree responses which is greater than the expected mean. From this mean value it was concluded that majority of the respondents positively accept that could easily communicate with their teacher and discuss on matters.

This finding was concomitant with the findings of Bayat (2015) which stated co-curricular member students were easily collaborate and communicate with their teammates and their coaches to discuss on matters encountering them.

\section{ii. Conflict Management Skills}

As it was explained by researchers such as Dhanmeher (2014), and Abrea (2015) students aquire conflict management through active participation on co-curricular activities. 
Table 3: Conflict Management Skills Development among Members of Co-Curricular Activities

\begin{tabular}{|c|c|c|c|c|c|c|c|c|c|c|c|c|c|c|c|c|}
\hline \multirow[t]{3}{*}{ Variables / items/ } & \multirow{3}{*}{$\begin{array}{l}\text { Respondent } \\
\mathrm{NS}=\mathbf{3 2 6} \\
\mathrm{NT}=\mathbf{5 0}\end{array}$} & \multicolumn{15}{|c|}{ Responses in five level Likert Scale } \\
\hline & & \multicolumn{2}{|c|}{$\begin{array}{l}\text { Strongly } \\
\text { disagree }\end{array}$} & \multicolumn{2}{|c|}{ Disagree } & \multicolumn{2}{|c|}{ Undecided } & \multicolumn{2}{|c|}{ Agree } & \multicolumn{2}{|c|}{$\begin{array}{l}\text { Strongly } \\
\text { Agree }\end{array}$} & \multicolumn{2}{|c|}{ statistics } & \multicolumn{3}{|c|}{$\begin{array}{l}\text { ANOVA between } \\
\text { group of students }\end{array}$} \\
\hline & & f & $\%$ & F & $\%$ & f & $\%$ & f & $\%$ & f & $\%$ & $\mathbf{x}$ & Sd. & $\begin{array}{l}\text { F. } \\
\text { obt }\end{array}$ & $\begin{array}{l}\text { F.cr } \\
t\end{array}$ & Sig. \\
\hline \multirow{3}{*}{$\begin{array}{l}\text { Member students get more opportunity } \\
\text { to discuss and decide in any matters in } \\
\text { co-curricular activity program }\end{array}$} & Students & 4 & 1.2 & 23 & 7.1 & 12 & 3.7 & 89 & 27.3 & 198 & 60.7 & 4.39 & 0.94 & .691 & 2.45 & .599 \\
\hline & Teachers & 0 & 0 & 5 & 10 & 0 & 0 & 28 & 56 & 17 & 34 & 4.14 & 0.85 & & & \\
\hline & Students & 2 & 6 & 5 & 1.3 & 4 & 1.2 & 38 & 11.7 & 277 & 85 & 4.79 & 0.59 & 1.98 & 2.45 & .097 \\
\hline \multirow{2}{*}{$\begin{array}{l}\text { Members of co-curricular activity are } \\
\text { judge on cases when it occurred. }\end{array}$} & Teachers & 0 & 0 & 1 & 2 & 1 & 2 & 30 & 60 & 18 & 36 & 4.30 & 0.61 & & & \\
\hline & Students & 33 & 10.5 & 130 & 39.9 & 26 & 8.0 & 76 & 23.3 & 61 & 18.7 & 3.01 & 1.33 & 2.196 & 2.45 & .069 \\
\hline \multirow{2}{*}{$\begin{array}{l}\text { When students catch conflicting idea, } \\
\text { they always claim issues to their teachers } \\
\text { rather than negotiating with each other }\end{array}$} & Teachers & 10 & 20 & 23 & 46 & 6 & 12 & 7 & 14 & 4 & 8 & 3.66 & 1.17 & & & \\
\hline & Students & 14 & 4.3 & 20 & 6.1 & 13 & 40 & 88 & 27 & 191 & 58.6 & 4.29 & 1.08 & 639 & 2.45 & .635 \\
\hline \multirow{2}{*}{$\begin{array}{l}\text { Members students believe in dialogue and } \\
\text { constructive discussion to solve } \\
\text { disagreements by them selves }\end{array}$} & Teachers & 0 & 0 & 0 & 0 & 1 & 2 & 23 & 46 & 26 & 52 & 4.50 & 0.54 & & & \\
\hline & Students & 2 & 0.6 & 24 & 7.4 & 19 & 5.8 & 85 & 26.1 & 196 & 60.1 & 4.38 & 0.93 & 1.029 & 2.45 & .392 \\
\hline $\begin{array}{l}\text { students able to negotiate between parties } \\
\text { when conflicting ideas arise }\end{array}$ & Teachers & 0 & 0 & 0 & 0 & 0 & 0 & 18 & 36 & 32 & 64 & 4.64 & 0.48 & & & \\
\hline
\end{tabular}

As can be shown in item 1 table 3 above, out of 326 total respond students 89 (27.3\%) agree and 198 (60.7\%) strongly agree that co-curricular member students could get more opportunity to discuss and decide in any matters in co-curricular activity program. For the same question out 50 total respondent teachers $28(56 \%)$ agree and 17 (34\%) strongly on the same statement. In aggregate out of 376 respondents $117(31.1 \%)$ agree and 215(57.2\%) strongly agreed that students get opportunity to discuss, and decide by themselves when conflicting ideas arises during their engagement and practicing different activities in co-curricular activity programs.

The mean value for respondent students, teachers and total are 4.39, 4.14, and 4.36 which are greater than the expected mean value three. It shows majority of the responds positively agreed that co-curricular activity member students could get opportunity to discuss and decided by themselves on raised conflicting ideas. The one-way ANOVA presented in table 3 indicated that F-obtained is 0.691 which is less than F-critical of 2.45 that show there is no significant difference between groups students from selected co-curricular activities in agreeing or disagreeing with the statement dictating students get opportunity to discuss as well as decide on cases. This finding clearly supported by finding of Dhanmeher (2014), Mancha, S.A. and Ahmed, A. (2016) and Bayat (2015) stating that co-curricular activity member students could develop skills that enable them to plan, organize different activities, discuss on it and made decisions. Even, they could able to manage budgets provided in supporting their co-curricular program.

In referring to the second question that stated about decision to be made, from 326 respondents about 315 (96.7\%) of students and from 50 respondents 48 (96\%) of sample teachers agreed that when there is conflicting ideas and actions happened students themselves collect evidence and judge on matter. As it was seen from table 3 above the mean value of student is 4.79 , that of teachers is 4.30 and in aggregate mean value of 4.72 which found close to strongly agree indicating students are able to judge on cases when it occurred.

Evidences obtained from school vice director through interview show that:

Each co-curricular activity found in their schools have established discipline committees that looks for cases and made decisions. Still yet, only rare cases which are beyond the capacity of students are passed to co-curricular activity coordinating teachers, whereas, almost all cases are handled by students themselves.

This finding was supported by Bayat (2015) co-curricular activity members made decisions together about whatever they doing. They have a chance to improve decisions in dialogues. The statically presented figures depicted in table 3, above showed that co-curricular activity member students got an opportunity to handle conflicts and able negotiate rather than merely claim it to their teachers. This finding was supported by works of Mancha, S.A. and Ahmed, A. (2016) who stated that students who are competence to manage conflict are able to negotiate and resolve disputes. The skills in managing conflict enable them to handle others as well as managing intense situation brightly. In addition, they are also able to detect potential conflicts in an atmosphere, handle disagreements openly and help in easing it. Their attitudes which are encourage debate and open discussion leads to problems adjustment in win-win situation.

Regarding the fourth question given in table 3 above, out of 326 respondent students about $279(85.6 \%)$ of students and out of 50 total respondent teachers $49(98 \%)$ of them, and out of total respondents $328(87.0 \%)$ were 
agreed that members students believe in dialogue and constructive discussion to solve disagreements happened.

The mean value for this question is about 4.29 for students, 4.5 for teachers and 4.32 in aggregate. These calculated mean values are by far greater than the expected mean value which is three. From these mean values one can concluded that majority of the students believe in dialogue and constructive discussion which in the long run help them to become rational person. The standard deviation for this question is $1.08,0.54$ and 1.00 for students, teachers and total respondents respectively. One-way ANOVA analysis presented table 3, revealed that F-obtained whose value is 0.639 which is by far less than F-critical 2.45 indicating that there is no significant difference between different groups of students in agreeing with the fact that co-curricular activity member students believe in dialogue and constructive discussion to solve disagreement. This finding was concomitant with the finding of Mancha, A.A. and Ahmed, A. (2016) and Dhanmeher (2014) stated that students who engaged in co-curricular activity become a peacemaker in detect potential conflicts among his colleagues, discussed on and avoided it to keep the harmonious relationship among students.

Last question used to see ability of students to manage conflict is about their capability of negotiating and arbitrating among students. That mean acting as third party, to bring the first and second party together to resolve disagreements. Out of 326 student majority of them that accounts for $281(86.2 \%)$, and $50(100 \%)$ of respondent teachers, and in aggregate $331(87.9 \%)$ of total respondents were agreed that students able to negotiate and /or arbitrate between parties when conflicting ideas raised.

As it was seen from the statistic column of above table 3 , the mean value for respondent students 4.38 , that of teacher 4.64 and total respondent is 4.41 which is greater than expected mean which is three indicating that respondents positively reacted that students could able to negotiate and arbitrate between parties when conflicting ideas raised. The standard deviations for this question are $0.93,0.48$, and 0.89 for students, for teachers and for total respondents respectively. This indicated that responses given by respondent are less deviated from the mean by less than one standard deviation and found concentrated around the mean. The analysis of variability also indicated that F-obtained is 1.029 which is less than F-critical 2.45 indicating that there is no significance variability between different groups of students from selected co-curricular activities in agreeing with the statement. From the analysis made it was concluded that co-curricular activity member students were developed skill of negotiation and arbitration. This finding was supported by findings of Bayat (2015) who stated in Evergreen school of Canada, members of social justice clubs were well arbitrate parties on cases provided for them.

\section{Psychological Skill Developments in Co-Curricular Activity} i. Self-Awareness Skill Developments in Co-Curricular Activity

Psychological skills development is one of the dimensions of human development. According to Dhanmeher (2014) students who took part in co-curricular activity have opportunity to develop basic psychological skill such as selfawareness, self-direction, self-confidence and able to manage themselves. The following question are used to measure respondents' level of agreement or disagreements in relation to psychological skill developments in terms of self-awareness. 
Table 4: Self-Awareness Skill Development of Students

\begin{tabular}{|c|c|c|c|c|c|c|c|c|c|c|c|c|c|c|c|c|c|}
\hline \multirow{4}{*}{$\begin{array}{l}. \mathrm{N} \\
\\
1\end{array}$} & \multirow{6}{*}{$\begin{array}{l}\text { Variables / items/ } \\
\begin{array}{l}\text { In co-curricular activity session, it is hard to } \\
\text { interact with each other among students from } \\
\text { different grade, sex, religion, ethnic }\end{array}\end{array}$} & \multirow{4}{*}{$\begin{array}{l}\text { Respondents } \\
\text { Students }\end{array}$} & \multicolumn{15}{|c|}{ Responses in five level Likert Scales } \\
\hline & & & \multicolumn{2}{|c|}{ St.disagree } & \multicolumn{2}{|c|}{ Disagree } & \multicolumn{2}{|c|}{ Undecide } & \multicolumn{2}{|c|}{ Agree } & \multicolumn{2}{|c|}{ St. Agree } & \multicolumn{2}{|c|}{ Statistics } & \multicolumn{3}{|c|}{$\begin{array}{l}\text { ANOVA between group } \\
\text { of students }\end{array}$} \\
\hline & & & $F$ & $\%$ & $F$ & $\%$ & F & $\%$ & $\mathbf{F}$ & $\%$ & $\mathbf{F}$ & $\%$ & $x$ & SD & F obt. & F. crt. & Sig. \\
\hline & & & 111 & 34 & 140 & 42.9 & 28 & 8.6 & 38 & 11.7 & 9 & 2.8 & 2.06 & 1.06 & 1.682 & 2.45 & .154 \\
\hline & & Teachers & 11 & 22 & 20 & 40 & 5 & 10 & 12 & 24 & 2 & 4 & 2.48 & 1.19 & & & \\
\hline & & Total & 122 & 32.4 & 160 & 42.6 & 33 & 8.8 & $\mathbf{5 0}$ & 13.3 & 11 & 2.9 & 2.22 & 1.09 & & & \\
\hline \multirow[t]{3}{*}{2} & \multirow{3}{*}{$\begin{array}{l}\text { Member students are shy and fear to interact } \\
\text { with co-curricular activity coordinating } \\
\text { teacher to express their feeling and discuss on } \\
\text { matter, thus they prefer to keep quite. }\end{array}$} & Students & 150 & 46 & 133 & 40.8 & 15 & 4.6 & 23 & 7.1 & 5 & 1.5 & 1.77 & 0.93 & .738 & 2.45 & .567 \\
\hline & & Teachers & 18 & 36 & 21 & 42 & 1 & 2 & 10 & 20 & 0 & 0 & 2.06 & 1.09 & & & \\
\hline & & Total & 168 & 44.7 & 154 & 41 & 16 & 4.3 & 33 & 8.8 & 5 & 1.3 & 1.81 & 0.96 & & & \\
\hline \multirow[t]{3}{*}{3} & \multirow{3}{*}{$\begin{array}{l}\text { Member students work in group and build } \\
\text { team sprit }\end{array}$} & Students & 5 & 1.5 & 4 & 1.2 & 9 & 2.8 & 45 & 13.8 & 263 & 80.7 & 4.71 & 0.72 & 1.205 & 2.45 & .309 \\
\hline & & Teachers & 0 & 0 & 0 & 0 & 2 & 4 & 23 & 46 & 25 & 50 & 4.46 & 0.47 & & & \\
\hline & & Total & 5 & 1.3 & 4 & 1.1 & 11 & 2.9 & 68 & 18.1 & 288 & 76.6 & 4.68 & 0.71 & & & \\
\hline \multirow[t]{3}{*}{4} & \multirow{3}{*}{$\begin{array}{l}\text { There is sense of inclusion and harmony } \\
\text { relationship among members of co-curricular } \\
\text { activity }\end{array}$} & Students & 12 & 3.7 & 14 & 4.3 & 16 & 4.9 & 85 & 26.1 & 199 & 61 & 4.37 & 1.01 & 1.949 & 2.45 & .102 \\
\hline & & Teachers & 0 & 0 & 3 & 6 & 2 & 4 & 27 & 54 & 18 & 36 & 4.2 & 0.78 & & & \\
\hline & & Total & 12 & 3.2 & 17 & 4.5 & 18 & 4.6 & 112 & 29.8 & 217 & 57.7 & 4.34 & 0.98 & & & \\
\hline \multirow[t]{3}{*}{5} & \multirow{3}{*}{$\begin{array}{l}\text { All members' co-curricular activities are easily } \\
\text { greeting their teacher and openly discuss } \\
\text { matter whenever they want. }\end{array}$} & Students & 3 & 0.9 & 17 & 5.2 & 7 & 2.1 & 69 & 21.2 & 230 & 70.6 & 4.5 & 0.85 & .176 & 2.45 & .951 \\
\hline & & Teachers & 0 & 0 & 4 & 8 & 3 & 6 & 17 & 34 & 26 & 52 & 4.3 & 0.91 & & & \\
\hline & & Total & 3 & 0.9 & 21 & 5.6 & 10 & 2.7 & 86 & 22.9 & 256 & 68.1 & 4.43 & 0.85 & & & \\
\hline
\end{tabular}

The first question used to see student's self-awareness stated about the fact that all co-curricular activity member students are able to manage their emotion and feelings such as anger, hatred, aggressiveness, etc. As a result, they kept them self from illegal actions. With this statement out of 326 respondent students 248 (76.1\%) of them agreed that students able to manage their emotion and feelings. Regarding respondent teachers, out of 50 respondents $31(62 \%)$ of respondent teachers agreed that co-curricular member students able to control their emotion. In aggregate about from 376 total respondents 279 (74.2\%) of them agree or strongly agreed that member students are able to manage their emotion and protect themselves from being involved in illegal actions.

As it was also seen from the above table 12 the mean value for respondent students is 4.04 , for teacher is 3.54 and aggregate value of both students and teachers is 3.99 which lies in bottom line of greed region. This indicate that respondents moderately accepted that students able manage their emotion and feelings. The F-test of oneway ANOVA showed that F-obtained is 0.501 which is less than one that indicated there was no significant difference between different groups of students selected from five co-curricular activities in agreeing with the statement.

Thus, from the analysis made it was concluded that students who engaged in co-curricular activities was able to manage their emotion, and feelings. This finding was supported by the finding of Bayat (2015) stating that skill of different member student complements each other in practicing co-curricular activities. They able to manage their emotion, and pressures in a game.

Regarding taking accountability and responsibility, out of 376 total respondents $331(88 \%)$ of them agreed or strongly agreed that co-curricular activity member students were take responsibility and accountability for any actions they undertake.

The aggregate mean value that account 4.48 in for respondent teachers and students lies almost in the middle of agree and strongly agree which are greater than expected mean value three found in undecided region. This show that majority of the respondent agreed that students take accountability and responsibility on what they are assigned to do. The value of standard deviation for response of students, teachers and both are $0.93,1.05$ and 0.95 which are less than one that indicate responses of students are deviate with less than one standard deviation showing that they are concentrated around the mean than teachers.

In supporting this finding Farrugia (2015), Jha et.al (2004), and Grahnzafar (2015) stated that students from co-curricular activity take responsibility to prevent themselves from illegal and harmful activities like drug abuse, criminal acts, and other form of harassments and channels their energy to fruitful activities. Furthermore, Bayat (2015) also explained that co-curricular activity member students able to take responsibility and ownership over their decisions and actions.

The fourth question is about identify what is good and bad and managing themselves in dos and don'ts. Out of 326 respondent students about 308 (94.5\%) of respondent students (of which $43(13.2 \%)$ agree and $265(81.3 \%)$ strongly agree) that member of co-curricular activity students able to differentiate between what is worth for them and not. From 50 respondent teacher $45(90 \%)$ of the teachers (out of which $26(52 \%)$ were agreed and $15(30 \%)$ strongly agree) agreed that students could identifies what is good and bad and mange themselves in dos and do 
not. In total out of 376 respondents 353 (93.9\%) of them (out of which 69 (18.4\%) were agreed and $284(75.5 \%$ strongly agreed) agreed that since students ascertain what is good and bad for themselves, they are confident on what they do and don'ts.

The one-way analysis made for this item showed that F-obtained is 1.534 which is less than F-critical of 2.45 indicating that there are no significance variabilities between different groups of students made of five selected co-curricular activities in agreeing with statement. The statement dictated that students could identify what is good and bad, so that they ascertain what to dos and do not.

In fact, the responses obtained through interviews with vice directors and woreda experts witnessed that: Majority of students know what to do and don'ts. They obliged to school's rules and regulations. Only few are rarely observed when the breach schools' rules and regulations and referred to school disciplinary committee.

From all this analysis made it was concluded that majority of students who participate in co-curricular activities were able to identified what is good and bad for them as a result decided on what they have to do and don'ts. the finding of Farrugia (2015), and Jha et.al (2004) further stressed students who engaged in co-curricular activities could able to prevent themselves from harmful activities like drugs, crime etc. It reflected that cocurricular activities enable students to become well-rounded, emotionally intelligent, and interpersonally skilled students who could able to decide on what is worth or worst for them.

The fifth question used to see student's self-awareness is related with the extent to which students direct their affair by themselves. From 326 respondent students about 307 (94.2\%) of them (out of which 62 (19\%) agree and $245(75.2 \%)$ strongly agree) that students could able to manage their affair by themselves. Regarding respondent teachers, out 50 respondents $45(90 \%)$ of respondent teachers (of which 22 (44\%) agree and 24 (46\%) strongly agree) also agreed that students manage their affair by themselves. In aggregate out of 376 total respondents 352 $(93.6 \%)$ of them (out of which $84(22.3 \%)$ agree and $268(71.3 \%)$ strongly agree) are agreed that members of cocurricular activities are direct their affair whether coordinating teacher is available or not.

As it was shown in table 4 the mean value for students' response is 4.65 , that of teacher's response is 4.3 and total respondents mean accounts for 4.6 which are greater than expected mean three implying that, majority of the responses is falls in between agree and strongly agree regions. It indicated that in aggregate $352(93.6 \%)$ of total respondents positively accepted that students in co-curricular activity were able to direct their affair independently. The standard deviation of responses of student which is 0.73 , that of teacher which is 0.85 and that total population which 0.75 showed that responses of respondent students and teachers were concentrated around the mean.

Regarding F-test for one-way ANOVA Table 4, showed that F-obtained for item five of self-awareness skill development is 0.626 which is less than F-critical of 2.45 that show there is no significance difference between different groups made of students in agreeing with the statement explaining that cocurricular activity member students direct their affair whether co-curricular activity coordinating teachers are available or not.

In general, from the table 4 given above, one can see that in aggregate, the smallest mean value is 3.99 and the highest is 4.58 that are greater than that expected mean value three. These showed that for all the five questions set to measure students' self-awareness, majority of the respondents are positively reacted to the question, which indicated co-curricular activities contribution to the development of self-awareness.

Research done by many scholars like Dhanmeher (2014), Bayat (2015), and Mbugua, Kaagema, and Nelson (2017) clearly indicated that - activities make students fit for the future time and enable them develop sense of competitiveness, cooperation, team sprit building, to enhance strong social interactions, self-discipline, selfawareness and self-directions.

\section{ii. Respect and Tolerance Skill Development}

Schools are social institutions that enable students to develop socio-culture values and skills among which one is respect and tolerance. Particularly co-curricular activities are occasions that bring students of different backgrounds together to work and interact with each other. Researcher like Dhanmeher (2004) emphasized roles of co-curricular activities is to develop skills such as respect among each other, tolerate each other, accept idea differences as normal conditions and appreciate their differences. To see this psychological skills development the following table is used. 
Table 5: Respects and Tolerance Skills Development among Co-Curricular Activities Member Students.

\begin{tabular}{|c|c|c|c|c|c|c|c|c|c|c|c|c|c|c|c|c|}
\hline \multirow[t]{3}{*}{ Variables / items/ } & \multirow{3}{*}{$\begin{array}{l}\text { Respondents } \\
N S=326 \\
N T=50\end{array}$} & \multicolumn{10}{|c|}{ Responses in five level Likert Scale } & \multicolumn{5}{|c|}{ Statistical Analysis } \\
\hline & & \multicolumn{2}{|c|}{$\begin{array}{l}\text { Strongly } \\
\text { disagree }\end{array}$} & \multicolumn{2}{|c|}{ Disagree } & \multicolumn{2}{|c|}{ Undecided } & \multicolumn{2}{|c|}{ Agree } & \multicolumn{2}{|c|}{$\begin{array}{l}\text { Strongly } \\
\text { Agree }\end{array}$} & \multicolumn{2}{|c|}{ statistics } & \multicolumn{3}{|c|}{$\begin{array}{l}\text { ANOVA between group } \\
\text { of students }\end{array}$} \\
\hline & & $\mathbf{F}$ & $\%$ & F & $\%$ & $\mathbf{F}$ & $\%$ & $\mathbf{F}$ & $\%$ & $\mathbf{F}$ & $\%$ & $\mathbf{x}$ & SD & F.obt & F.crt. & Sig. \\
\hline \multirow{2}{*}{$\begin{array}{l}\text { There is healthy exchange of ideas and good } \\
\text { fellow feelings among member of co-curricular } \\
\text { activity. }\end{array}$} & Students (326) & 1 & 0.3 & 5 & 1.5 & 8 & 2.5 & 83 & 25.5 & 229 & 70.2 & 4.64 & 0.64 & .637 & 2.45 & .637 \\
\hline & Teachers (50) & 0 & 0 & 3 & 6 & 3 & 6 & 18 & 36 & 26 & 52 & 4.34 & 0.84 & & & \\
\hline \multirow{2}{*}{$\begin{array}{l}\text { Member students recognize difference among } \\
\text { members based on religion, ethnic, sex, grade, as } \\
\text { normal occasion. }\end{array}$} & Students (326) & 3 & 0.9 & 3 & 0.9 & 4 & 1.2 & 67 & 20.5 & 249 & 76.4 & 4.71 & 0.63 & .580 & 2.45 & .677 \\
\hline & Teachers (50) & 1 & 2 & 1 & 2 & 1 & 2 & 30 & 60 & 17 & 34 & 4.22 & 0.76 & & & \\
\hline \multirow[t]{2}{*}{ Members accept victory and defeat in grace. } & Students (326) & 8 & 2.5 & 17 & 5.2 & 11 & 3.4 & 61 & 18.7 & 229 & 70.2 & 4.49 & 0.96 & .487 & 2.45 & .745 \\
\hline & Teachers (50) & 2 & 4 & 3 & 6 & 2 & 4 & 17 & 34 & 26 & 52 & 4.24 & 1.06 & & & \\
\hline \multirow{2}{*}{$\begin{array}{l}\text { Members feel unity and belonging to same co- } \\
\text { curnicular activity. }\end{array}$} & Students & 7 & 2.1 & 8 & 2.5 & 13 & 4 & 64 & 19.6 & 234 & 71.8 & 4.56 & 0.85 & .712 & 2.45 & .584 \\
\hline & Teachers & 0 & 0 & 3 & 6 & 3 & 6 & 23 & 46 & 21 & 42 & 4.24 & 0.82 & & & \\
\hline \multirow{2}{*}{$\begin{array}{l}\text { the more students engaged in co-curricular } \\
\text { activity, the more they develop culture of } \\
\text { appreciation, encouragement and understanding }\end{array}$} & Students (326) & 5 & 1.5 & 8 & 2.5 & 10 & 3.1 & 45 & 13.8 & 258 & 79.1 & 4.67 & 0.78 & .989 & 2.45 & .413 \\
\hline & Teachers (50) & 1 & 2 & 2 & 4 & 1 & 2 & 19 & 38 & 27 & 54 & 4.88 & 0.87 & & & \\
\hline
\end{tabular}

The first item used to measure students' skill of respect and tolerance designed to see the extent to which there is healthy exchange of ideas and good fellow feelings among member of co-curricular activity. In responding to this statement out of 376 total respondents that account for $326(94.7 \%)$ of them were agreed that co-curricular activity member students have developed a culture of healthily exchanging idea and have good fellow feelings toward each other.

As it was seen from the above table 13 the mean values of respondent are 4.6 which indicate the mean value of response fall in between agree and strongly agree. This clearly showed majority were positively reacted to the statement supporting that co-curricular activity member students have developed habit of healthy exchange of ideas and good fellow feelings toward each other. The one-way ANOVA presented in Table 4, revealed that Fobtained 0.637 which less than F-critical 2.45 . This ANOVA value indicated that there is no significance variability between mean values of respondent students from groups of selected co-curricular activities in agreeing with idea that students developed culture of healthy exchange of ideas and developed good feelings toward each other.

In supporting the stated finding Ghanzafar (2015) find out that about 58\% of respondents agreed that students who participate in co-curricular activity expose way to work in collaboration and efficiently with other whose points of view may be different from their own. Thus, co-curricular activity brought together students from different social class and idea together around common theme.

Regarding second question that focused on the fact that member students recognized differences existed among themselves based on religion, ethnic, sex, and grade as normal circumstance. Out of 376 total respondents of both students and teachers 333 (96.5\%) of them (in which 97 (25.8\%) agree and 266 (70.7\%) strongly agree) that there is culture of recognizing each other among students involved in co-curricular activities. This fact could also be supported by respondent teachers in such a way that out of 50 respondent teachers 47 (94\%) of them (30 $(60 \%)$ were agreed and 17 (34\%) were strongly agreed) agreed that there is culture of recognizing each other and accepting differences among students as natural phenomena.

The mean of respondent students which is 4.71 , that of respondent teachers which is 4.22 and mean value of total respondent which 4.64 is much higher than expected mean value three. These calculated means revealed that majority of the respondent students and teachers were positively reacted that there is culture of recognizing individual differences based on sex, grade, religion and ethnicity among member of co-curricular activities. As revealed from table 12, the standard deviation of respondent students, teachers, and total respondent for the item number two are $0.63,0.73$, and 0.67 that show there is less deviance of responses from mean and from each other by less than one standard deviation. This indicated that responses are distributed in concentration around the mean. The one-way ANOVA of F-statistics showed that F-obtained as presented in Table 4, is 0.580 which is less than F-critical 2.45 showing that there is no significance difference between respondents from different groups of students engaged in five selected co-curricular activities. This insignificant variability is in agreeing with the statement that indicate member students recognize difference observed among themselves inform of religion, ethnic, sex, grade, as normal occasion.

From all the analysis made it was concluded that co-curricular activities are batter ground for development of skills to recognize differences among students from diversified backgrounds that manifested in terms of religion, ethnic, sex, grade. This finding is supported by work of Bayat (2015) stated cooperation, teamwork, and inclusiveness are noticeable among students from different grade, sex and ethnicities. When student work together they realize everybody is more similar than they are differ.

Concerning the third questions that reflects the idea as co-curricular activity members students accept both victory and defeat in grace. In reacting to this fact, out of 326 total respondent students $290(88.9 \%)$ of respondents 
agreed that member of co-curricular activities was accept victory and defeat in grace. Regarding respondent teachers out of 50 total respondents $43(86 \%)$ of respondents (of which $17(34 \%)$ were agreed and $26(52 \%)$ were strongly agreed) were agreed that co-curricular activity member students are positively accept whether their idea win or loss in grace.

The mean value of respondent students, teachers, and total respondents were $4.49,4.24$, and 4.46 respectively. This mean value indicated that majority of the respondents were agreed that accept victory and defeats in good will. The standard deviation of this question three were 0.96 for responses of students, 1.06 for teachers and 0.98 for total respondents that revealed there was less deviance in distribution of responses of both students and teachers from the mean.

The writers assumed that in agreeing or disagreeing with the items presented, there is no significant difference between group of students. To realize this fact the one-way ANOVA analysis was used showing that F-obtained 0.487 which is less than F-critical 2.45 that indicate there is no significant difference between different groups students made of five selected co-curricular activities in agreeing with question that stated co-curricular member students accept victory and defeat in grace. Therefore, the assumption of the researcher was contained.

From this analysis it was concluded that co-curricular activity enables students to develop democratic culture that help student accept victory and defeat of their idea peacefully as a rationale person believing in reasoning. In supporting this finding, Dhanmeher (2014) co-curricular activities promote students' personality development by widening up their reasoning capacity, their potential to think rationally, provide opportunity to better character buildings for leadership.

The fourth statement used to measure respondents' agreement or disagreement toward the existence of respect and tolerance among student is unity and belongingness. In reacting to this, out of 376 total respondents 342 $(90.9 \%)$ (out of which $87(23.1 \%)$ were agreed and $255(67.8 \%)$ were strongly agreed) agreed that there is sense of unity and belongingness to same co-curricular activity among members students. The mean values of respondent students which is 4.56 and that of respondent teachers is 4.24, and in aggregate accounts for 4.52 reflected that majority of respondents positively accepted that there are unity and belongingness among co-curricular activity member students. The standard deviation of responses of students, teachers and total respondent were $0.85,0.82$, and 0.85 respectively. This value of standard deviation shows that the responses given by respondents are concentrated around the mean with less than one standard deviation.

The writers assumed that in agreeing or disagreeing with idea of question four used to measure respect and tolerance among students, there is no significance difference between group of students made from five selected co-curricular activities.

To test this the one-way ANOVA presented in Table 4, revealed that F-obtained 0.712 which is less than Fcritical 2.45 that show there were no significant variation among different groups of students from the five selected co-curricular activities in agreeing with question four that dictated there are unity and belongingness among students. Therefore, the assumption of the researcher was contained that there is no significance difference between group of students in agreeing with statement. This finding was also supported by Dhanmeher (2014) explained co-curricular activity as means to develop special quality as to bring power for unity and oneness.

The fifth question used to measure respect and tolerance is related with the fact that the more students engaged in co-curricular activity, the more they develop culture of appreciation, encouragement and understand of each other. To this fact as it was seen from table 11 given above, out of 376 total respondents about $349(92.8 \%)$ of them (out of which $17 \%$ agree and $75.8 \%$ strongly agree) agreed that by being participated in co-curricular activities, students get more opportunity to further appreciate, encourage and understand each other.

The mean value of respondent students, and teachers, and total respondent were 4.67 and 4.88 , and 4.63 respectively These mean values revealed that majority of respondents positively agreed with the statement that indicated the more student engaged in co-curricular activity, the more they developed culture of respect and tolerance manifested through appreciation, encouragement and understanding of each other.

\section{Challenges Encountering in Practicing Co-Curricular Activity}

Many researches done in co-curricular activity showed that the practice of co-curricular activities was not successfully carried out without obscuring challenges. The following table 12 depicts that challenges encountering co-curricular activities in upper primary schools of Sinana woerda that listed down according to its descending order based on values given by respondent students and teachers. 
Table 6: Challenges Encountering the Practices of Co-Curricular Activities

\begin{tabular}{|c|c|c|c|c|c|c|}
\hline \multirow[b]{2}{*}{ R.N } & \multirow[b]{2}{*}{ Items } & \multicolumn{5}{|c|}{ Descriptive Statistics } \\
\hline & & $\mathrm{N}$ & $\sum$ & $\mathrm{X}$ & Rank & SD \\
\hline 1 & $\begin{array}{l}\text { Material resources such as shelf, table chair, stationaries } \\
\text { and other co-curricular activity related materials are not } \\
\text { sufficiently provided. }\end{array}$ & 376 & 4108 & 10.93 & 1 & 4.252 \\
\hline 2 & $\begin{array}{l}\text { There is no enough equipment to support co-curricular } \\
\text { activity }\end{array}$ & 376 & 4005 & 10.65 & 2 & 4.034 \\
\hline 3 & $\begin{array}{l}\text { Co-curricular activity coordinating teacher is busy due } \\
\text { to teaching load }\end{array}$ & 376 & 3725 & 9.91 & 3 & 4.325 \\
\hline 4 & $\begin{array}{l}\text { All necessary physical facilities and infrastructures } \\
\text { such as training fields, hall, office, water, light etc. are } \\
\text { not available in our school to enhance activities of } \\
\text { cocurricular. }\end{array}$ & 376 & 3593 & 9.56 & 4 & 3.775 \\
\hline 5 & $\begin{array}{l}\text { School do not give due emphasis to co-curricular } \\
\text { activity }\end{array}$ & 376 & 3530 & 9.39 & 5 & 3.822 \\
\hline 6 & $\begin{array}{l}\text { Co-curricular activity coordinating teachers lack } \\
\text { training to effectively manage and coordinate our } \\
\text { activity }\end{array}$ & 376 & 3262 & 8.68 & 6 & 4.412 \\
\hline 7 & $\begin{array}{l}\text { There is no awards and incentives program for those } \\
\text { who perform well in co-curricular activities }\end{array}$ & 376 & 3184 & 8.47 & 7 & 3.915 \\
\hline 8 & $\begin{array}{l}\text { students do not have enough time to regularly } \\
\text { participate in co-curricular activity }\end{array}$ & 376 & 2923 & 7.77 & 8 & 4.548 \\
\hline 9 & $\begin{array}{l}\text { We do not have all necessary plans such as annual, } \\
\text { semester, and quarterly plan for co-curricular activity }\end{array}$ & 376 & 2793 & 7.43 & 9 & 3.748 \\
\hline 10 & $\begin{array}{l}\text { Vision, Goals and values of co-curricular activity are } \\
\text { not well communicated to students. }\end{array}$ & 376 & 2655 & 7.06 & 10 & 3.465 \\
\hline 11 & There is no guideline for co-curricular activity & 376 & 2546 & 6.77 & 11 & 3.667 \\
\hline 12 & $\begin{array}{l}\text { Students are overburdened with academic program, } \\
\text { they don't have enough time to do well in co-curricular } \\
\text { activity }\end{array}$ & 376 & 2422 & 6.44 & 12 & 4.006 \\
\hline 13 & $\begin{array}{l}\text { Co-curricular activities are active only when school } \\
\text { begun at new academic year and gradually decline. }\end{array}$ & 376 & 2359 & 6.27 & 13 & 4.100 \\
\hline 14 & $\begin{array}{l}\text { Since co-curricular activity affect students' study time, } \\
\text { they are not well involved in co-curricular activity }\end{array}$ & 376 & 2027 & 5.39 & 14 & 3.180 \\
\hline 15 & $\begin{array}{l}\text { Students are not interestedly involved in co-curricular } \\
\text { activity }\end{array}$ & 376 & 1963 & 5.22 & 15 & 3.783 \\
\hline & Valid & 376 & & & & \\
\hline
\end{tabular}

As table 5 clearly depicted, it was the ranking / rating scale that was used to identify the top most critical challenges that obscure the effectiveness of co-curricular activity in upper primary schools in Sinana Woreda. From this table, although all 15 listed factors negatively influence effectiveness of co-curricular activities, based on its mean values, top five challenges listed in descending order includes Material resources such as shelf, table chair, stationaries and other co-curricular activity related materials are not sufficiently provided, There is no enough equipment to support co-curricular activity, co-curricular activity coordinating teacher is busy due to teaching load, All necessary physical facilities and infrastructures such as training fields, hall, office, water, light etc. are not sufficiently available in school to enhance activities of co-curricular and School administrations do not give due emphasis to co-curricular activity.

Whereas, the least challenges that have no significant effect on co-curricular activities performance are those listed from $11^{\text {th }}$ to $15^{\text {th }}$ rank order given in the above table 5. Surprisingly, information obtained from an interview made with schools' vice director showed that the main challenges that adversely affect performance of cocurricular activity are lack budget to fulfill all the necessary materials, stationaries, offices and offices equipment. Furthermore, they also stated that schools are in budget constrained to fulfill all the necessary facilities and infrastructure which coincides with challenges identified with respondent students and teachers. Not only for cocurricular activities, but also for the whole school's academic program too, schools have not well equipped, and facilitated.

The other critical challenge is teachers over load. Majority of vice directors responded that teachers are obliged to teach up to 30 period per week. Besides, they are forced to provide tutorial class, to coordinate cocurricular activities and to be involved in different school-based committees. Thus, teachers are highly 
overburdened. Responses from woreda expert also support this idea by stating that based on internal inspections conducted by woreda education office, almost all upper primary schools of Sinana woreda are under the standard set by ministry of education. Particularly, when schools are measured in terms of availability of physical facilities such as buildings, different offices, and teacher's quantity and qualification, majority of them are below standard. In my observation too, there is no single co-curricular activities that have separate office but, two to three cocurricular activity have single office in common. No attractive sport fields, no attractive offices, no sufficient stationaries necessary to run the activities, and no commitment to give support with existing materials from school administration.

Findings of Rajanda (2014), Jha (2004), Bayat (2014), and Mbugua, Kaagema, and Nelson (2017) are concomitant with the identified challenges by stating that schools commonly lack basic physical facilities necessary to effectively run co-curricular activities, lack of necessary resources, lack of income or provision of fund, irregularity of teachers, and poor follow up and monitoring. Besides, lack of equipment, financial and material resources, lack of training for co-curricular activity coordinating teachers, teaching over load, and weak attention from concerned body are major bottle necks identified.

\section{Summary, conclusions and recommendations Summary}

The main objective of this research article was to investigate co-curricular activities and its contributions for psychosocial skills development of students in upper primary schools of Sinana Woreda, Bale Zone, Oromia. Hence, based on analysis and interpretation of data, research findings were summarized under each theme as follows.

$\checkmark$ Regarding social skills development the research find out that students who took part in co-curricular activities were grasped necessary skills that help them to build and master good relationship among each other and with their teachers. This finding was realized through evidences from respondents. 282(75\%) of total respondent opposed the difficulty to interact with students from different background. Further $222(85.7 \%)$ of total respondent believed that co-curricular activity member students don't fear and shy to interact with their teacher. Thus, they easily express their feeling without self-restriction. In addition, $356(94.7 \%)$ of total respondent justified that students who engaged in co-curricular activity could able to build team spirit that further boost their familiarity with each other. Thus, it was easy for students to develop sense of inclusion and harmonic relationship that further strengthened their intimacy to each other and with their teacher to easily communicate, and openly discuss on cases.

$\checkmark \quad$ In referring to conflict management skills, this research work finds out that co-curricular activities could enable students to manage conflicts. By being participate in co-curricular activity they prefer to join, they get opportunities to discuss and decided on cases, able to judge by themselves rather than diverting everything to their teacher. Furthermore, practices in co-curricular activities empowered them and lift up their capacity to made constructive dialogue and mediate cases between parties to dissolve disagreements. These findings were evidenced with majority of the respondents. Supporting evidence showed that 332 $(88.3 \%)$ respondents agreed that students get opportunity to discuss on matters, $363(96.6 \%)$ of total respondent believed that students able to judge, and $328(87.0 \%)$ of total respondent positively support students could conduct constructive dialogue with each other and out of total respondents $331(87.9 \%)$ of the supported that students develop skills of negotiating students having different cases.

$\checkmark$ Regarding psychological skills, the research work finds out that co-curricular activities help students to escalate their skills of understanding themselves and give respect and tolerate each other in their daily life. Engagement in co-curricular activities benefit students to moderately manage their emotion and feelings. Furthermore, practices in co-curricular activity support their efforts to take informed responsibility and accountability in any actions they take. In addition, students those who engaged in cocurricular activity develop skills to identify what is worth and worst for their life, as a result decided on what to do and don'ts.

$\checkmark \quad$ In referring to the development of skills of respects and tolerance, the research finds out that majority of total respondent $356(94.7 \%)$ agreed that there is healthy exchange of ideas and good fellow feelings. In addition, 363 (96.5) of total respondent witnessed that students could able to recognized individual differences and further strengthened their unity and oneness. Besides, 333(88.3\%) of total respondents believed that students accepted their victory and defeats as normal occasion. It was also evidenced that the more students engaged in co-curricular activities the more they understand each other and narrow their differences.

$\checkmark$ Regarding challenges encountering, out of 15 different cases presented as potential challenges that bottlenecked the proper functioning of co-curricular activities respondents rated out the top-five challenges that obscured their effective performances. In its descending order this includes, lack of sufficient material resources such as shelf, table chair, stationaries and other co-curricular activity related 
materials, unavailability of enough equipment to support co-curricular activity, teachers teaching over load, insufficiency of physical facilities and infrastructures such as training fields, hall, office, water, light etc. ill-provision of emphasis to co-curricular activity that end up with weak follow up, and monitoring and evaluation.

\section{Conclusions}

Based on the summary of the findings of the study, the following conclusions were made.

$\checkmark$ Majority of the respondent students and teachers agreed that practicing in co-curricular activity has played pivotal role in boosting social skills such as building strong relationship and managing disagreements and outbreak conflicts. Though there were socio cultural differences among cocurricular activity member students in terms of sex, religion, ethnic and grade they attained, they easily interact, cooperate, and form strong social bonds. They greet and discuss ideas with their teacher without any limit, and thus able to build strong team spirit, feel sense of inclusion, and form harmonic relationship among themselves.

$\checkmark \quad$ By being involved and actively participated in co-curricular activities, majority of the respondents that account for more than $320(85 \%)$ witnessed that students get opportunity to discussed and decided on agenda set, able to judge on cases occurred, and played as third party to negotiate and further to mediate and arbitrate when there were disagreements among different parties. Furthermore, they get opportunity to develop reasoning ability, believing in dialogue and held constructive discussions to convince each other. However, respondent that holds about 148 (39.4\%) were agreed that there were occasions when students bring claimed issues to their teacher for resolution rather than solving by themselves.

$\checkmark$ One of the benefits of co-curricular activity is its contribution to the personality development that help students to manage their emotion and feelings. To this end, large number of respondents that reached $279(74.2 \%)$ agreed that students who participate in co-curricular activity are able to control their emotions expressed in form of anger, hate, aggressiveness, and annoyances. Divergently, about 75 $(20 \%)$ of respondent believed that there is inability to control emotion among students.

$\checkmark$ Respondents that account for $338(90 \%)$ and above believed that students who engaged in cocurricular activity develop capacity to take on responsibility and accountability, built sense of identify what is good and bad for themselves, direct their affairs without being waiting for co-curricular activity coordinator.

$\checkmark$ Ethiopia is one of the world countries that termed as a mosaic of socio-cultural diversity. Schools are the miniature of society in which diversities within society reflected in it. For the formation of strong social cohesion among such diverse society, development of psychosocial skills such as respect and tolerance among new generation is crucial. To this reality, out of the total respondents $300(80 \%)$ and above agreed that co-curricular activities are enabling instruments for the development of healthy exchange of ideas, good fellow feelings, and recognition of differences. Even it enables students to accept both victory and defeats in grace. Furthermore, majority of the respondents believed that cocurricular activity empowers them to build unity and sense of belongingness. Therefore, the more students engaged in co-curricular activity the more they advance in appreciating, encouraging and understanding each other.

$\checkmark$ Even though there is better participation, practicing, and psychosocial skill development in cocurricular activities held in upper primary schools of Sinana woreda Bale zone, Oromia, there are critical challenges that hamper the optimum performance of co-curricular activity with its full capacity, encouragement and initiations. Among many challenges list out by respondents, the most critical top five identified includes lack of sufficient material resources such as office and office equipment (chairs, table, stationaries, shelfs, etc. that help to run day to day activities) that took the first line challenge. Others includes, lack of additional equipment used to accomplish planned activities, cocurricular activity coordinating teachers are busy with teaching loads, lack of quality physical facilities and infrastructures such as training fields, halls, water, electric power, and so on. The other challenges identified as top five is lack of emphasis from school administration that linked with activities such as effective follow up, timely monitoring and evaluation, providing incentive, rewards and related encouragements.

\section{Recommendations}

Based on the findings and conclusion of the study, the following recommendations were forwarded.

$\checkmark \quad$ In upper primary schools of Sinana woreda, there are better students' participations and practices in cocurricular activities. However, there were less in displaying what was performed according to plan and schedule set, less culture of strict performance evaluation, provision of awards and incentives where not 
habituated. Therefore, co-curricular coordinating teachers and co-curricular activity committee of students together with school administration have to regularly conduct performance evaluation as per the schedule set, create conduce room for displaying what was done by students, and arrange the provision of rewards and incentives for those who perform well in order to make co-curricular activity more enjoyable, attractive and learning ground.

$\checkmark$ The emphasis given to co-curricular activity by governing body particularly, by school administration and Cluster Resource Center (CRC) Supervisor was very less. The follow up, monitoring and evaluation mechanism were not deep rooted and regular, but it was done haphazardly. Therefore, to maintain the existing potential avail within students and initiations of co-curricular activity coordinating teachers, school administration and woreda education office have to design mechanism to provide moral and material supports for the co-curricular activity participants.

$\checkmark$ As it was highly emphasized in conclusion par, respondents strongly agreed with role of co-curricular activities in developing psychosocial skills. However, to the contrary, schools are immersed in tremendous challenges that sharply bottleneck and consume up students' effort and coordinating teachers' commitments. Therefore, schools' administrations together with surrounding community and woreda education office have to timely resolve these challenges by employing different fund rising mechanisms to fulfill all the necessary resources, equipment and facilities necessary to better boost the performance of students in co-curricular activity.

$\checkmark \quad$ Last but not least, to fruitage co-curricular activities better, and to made it more recognizable and inclusive, the schools had to fix annual co-curricular activities day officially.

\section{References}

Abrea, R. R. (2015). "Status of co-curricular and extra class activities of students' organizations from selected territiary institutions in Philippins". Asian pacific journal of multidisciplinary research. Vol, 3. No, 4. pp. 5965.

Annu, S. and Sunita, M. (2014). "Extra-curricular activities and students' performance in secondary schools". Ambedker University, India. International Journal of Technological Research and Publications. Vol.2 issue. 6 Nov-Dec 2014, pp.08-11

Ayele, Ishete. (2007). Practices of extra-curricular activities in Addis Ababa University. A research paper for partial fulfilment of the requirement of masters of Art curriculum and instruction. Addis Ababa University.

Bayat, F. (2015). Students Engagement: A qualitative study of extracurricular curricular activities. A research paper for partial fulfilment of the requirement of Doctor of Education. University of Toronto, Canada.

Best, J.W. and Kahn, J.V. (2006). Research in education. 10 ${ }^{\text {th }}$ ed. Pearson Education Inc.

Chingtham, T. (2016). "Co-curricular activities program of government and private schools: A comparative study". IOSR Journal of Research and Method in education. Vol,6. Issue,2.

Creswell, J.W. (2009). Research Design: Qualitative, Quantitative, and Mixed Research methods approaches. $3^{\text {rd }}$ ed. University of Nebraska-Lincoln. SAGE publication Inc.

Dhanmeher, B.R. (2014). Impact of co-curricular activities on non-academic development of junior college students. A Dissertation paper for partial fulfilment of the requirement of Doctor of Philosophy in Business management. DYPATIL University, Navi-Mumbai.

Farrugia, T. (2015). Extra-curricular activities: the perception of graduates on how students' engagement affects career development: A qualitative study, University of Malta.

Gill, R.s. (2015). "A study of co-curricular activities in relation to adjustment among adolescents". international multi-disciplinary e-journal. Vol, 5. Issue, 3. pp 133-139

Jha, A.k., Rai, P.B., Joshi, G.P. and Giri, A. (2004). Status of co-curricular and extra-curricular activities in primary schools of Nepal: Problems and prospects. Tribhuvan University, Nepal.

Joseph, C.M. (2003). Implementing extra-curricular activities in schools of India: the case of Pwashakari Districts. University of Delhi. India.

Kisango,B.(2016). Factors influencing students' participation in co-curricular activities in public secondary schools in Lamu County, Kenya. A Research paper for partial fulfilment of the requirement of Masters of Education Degree in Curriculum Studies. University of Nairobi.

Mancha, J.A. and Ahmed, A. (2016). Co-curricular Activities and its effect on Social Skills. International conference on education. Cross-Cultural education for sustainable regional development. Badung, Indonesia.

Mbugua, Z., Kagema, J. and Nelson, M. (2017). “Assessment of secondary schools Teachers participation in cocurricular activities in Kirinyaga central sub country, Kenya”. International Journal of humanities and social sciences. Vol, 7. No, 4. pp. 192-199

MoE (2015). Education Sector Development Program V (ESDP-V). Program Action Plan. Addis Ababa, Ethiopia. MoE (1994). Education and Training policy. Addis Ababa, Ethiopia.

Nilson, N. (2009). Impacts of extra-curricular activities on students. A research paper for partial fulfilment of the 
requirement of Masters of Science in school counseling. University of Wisconsin-Stout.

Panigrahi, M.R. and Yadessa, B. (2012). "Implication of co-curricular activities in secondary schools of Oromia special Zone Surrounding Finfinnee". Haramaya University, Ethiopia, Africa. An international multidisciplinary peer review and journal. Vol, 1. Issue, 4. pp. 190- 213

Paul, P.k.and Baskey, S. K. (2012). "Roles of co-curricular activities on academic performance of students: a case study in some secondary schools of Burdwan District in West Bengal, India". International journal of innovative research and development. Vol, 1. Issue, 9. pp.213-223

Saleem, I.R. (2010). "Role of co-curricular activities: Survey of the perceptions of stake holders. Case of Peshawar district, Pakistan”. Journal of Managerial Sciences. Vol, 2. No, 2. pp 214-219

UNICEF (2014). Schools club in Ethiopia. A Briefing note, media and external relation section. Addis Ababa Ethiopia.

Yamane, T. (1967). Statistics: an introductory Analysis. $2^{\text {nd }}$ ed. New York. 